\title{
Cellulase digestion technique compared with the in vitro digestibility of forages
}

\author{
Seppo Pulli \\ University of Helsinki, Department of Plant Husbandry, Viikki
}

\begin{abstract}
A red clover-grass mixture and a couch grass (E. repens) pure stand were studied at eighteen different stages of maturity in Viikki. The analytical techniques were a cellulase digestion method and a two stage in vitro digestion technique. A high correlation $\left(r=.99^{* * *}\right.$ for both types of stand and residual standard deviations (RSD) of 0.9 and 1.3 respectively) was found between cellulase DM digestibility and in vitro DM digestibility. The difference between cellulase and in vitro DM digestibility increased as the plants advanced in maturity, because the effect of enzyme decreased, as the plants were more matured. The relationship between cellulase DM digestibility and plant protein content was very close, $\left(\mathrm{r}=.99^{* * *}\right.$ for the clover-grass mixture and couch grass and RSD's of 0.6 and 0.5 respectively). At the early stages of maturity when the plant protein content and in vitro DM digestibility were high, the cellulase technique digested more efficiently the clover-grass mixture than the couch grass. The cellulase method was rapid, reproduciple and well suited to the evaluation of the plant material studied.
\end{abstract}

\section{Introduction}

Forage feeding value is dependent on the levels of available energy and protein and the palatability of the forage. The main determinant is considered to be the amount of digestible energy per unit weight. As the feeding value of the forage varies greatly according to the maturity, species and the environment of the plant, the important point is to test not only the constituents, but also the digestibility of the roughage. For this purpose, considerable efforts have been made to develop a method which would give reliable digestibility results without the need to resort animal trials.

SALo (1973) has reviewed the methods used in the estimation of the digestibility. According to the review, the raw fibre has long been used as a parameter of the digestibility (Mc Menkan 1943, Griffith and Thomas 1955 and KIVImÄe 1960). The techniques do not predict very well the digestibility of feeding material. The normal acid fibre (NAF) (GRIFFith and Thomas 1955) and acid detergent fibre (ADF) (VAN SoEST 1963) techniques are also not considered adequate. The content of lignin has a little better correlation than raw fibre with the digestibility of roughage (ARMSTrong et al. 1964). The most important method used today is probably the in vitro rumen fermentation technique. Especially the two stage technique of TILlEy and TERry (1963) is widely used to the assessment of digestibility. 
An inherent disadvantage of fermentation techniques is their dependence on a supply of rumen inoculum, requiring access to animals fitted with rumen canulae and fed under controlled conditions to minimize variations in the composition of the rumen liquor (Jones and HAYWARD 1973). Several workers (Drew 1966, Troelsen and Hanel 1966, Yates and Allden 1966) have reported variations in in vitro results due to variations between animals, composition of diet, time of sampling relative to feeding etc.

In the technique of TILLEY and TERRY (1963), the first stage is a digestion by enzymes originating from the rumen microbes. The digestion is completed by a commercial pepsin preparation. The pepsin technique has directed attention to the use of other enzyme preparations. The use of freeze-dried enzyme preparations as digesting agents has obvious advantages over in vitro methods, which involve more difficult techniques and are subject to wide variations. However, Donofer et al. (1963) in their first attempt found a poor correltion between cellulase and in vivo digestibility. JARRINGE et al. (1970) found a better correlation between cellulase and in vivo digestibility than between in vitro and in vivo digestibility. GugGolzt et al. (1971) also found a good correlation between in vivo and cellulase digestibility. ABE et al. (1973) used 4,8 and 12 hours cellulase digestion periods and found excellent correlations between cellulase digestibility and in vivo digestibility, as teh values $\mathrm{r}=$ $99,7,99.9,99.7$ respectively and $\mathrm{p}<0.01$ show.

BAIley and Jones (1971) and Jones and BaIley (1972) have used a crude cellulase preparation from Trichoderma viride as a hydrolytic agent to study the rate of hydrolysis of cell walls in grasses. The effect of the treatment was relatively poor, but the correlation with in vivo digestibility satisfactory. Later JoNES and HAYWARD (1973) examined the use of a commercially available enzyme from the same fungus as a digesting agent for predicting herbage digestibility. A high correlation $\left(\mathrm{r}=.92^{* * *}, \mathrm{RSD}=2.5\right)$ was found between results from a simple one stage enzyme digestion and in vivo DM digestibility for a range of grass apecies and varieties. A crude cellulase preparation showed cellulase, hemicellulase and proteolytic activity.

This paper examines the use of a crude cellulase preparation as a digesting agent compared with a determination of in vitro digestibility. The material consists of two types of roughage, a red clover-grass mixture and couch grass (Elytrigia repens) sampled at eighteen different stages of maturity. Other objects of the study are the relationships between the cellulase digestibility and plant protein content at different stages of plant maturity. The main purpose is to test the feasibility of cellulase techniques for agronomists and plant breeders, so that the use of animals could be avoided.

\section{Experimental}

\subsection{Materials}

Two types of roughage, a red clover grass-mixture (average of samples during season: red clover $31 \%$, timothy $32 \%$, Festuca $24 \%$ others $13 \%$ ) and couch grass (E. repens) were studied at eighteen different stages of maturity 
during the 1974 growing season. The first sampling date was May 23.Sampling was completed on July 22. Four replications of the material were collected three times a week, oven-dried at $70^{\circ} \mathrm{C}$ and ground to pass a $0.6 \mathrm{~mm}$ sieve.

\subsection{Analytical techniques}

In vitro dry matter digestibility was determined by the two stage technique of TIlley and TERRY (1963). The cellulase used was a preparation from Trichoderma viride, marketed by BDH Ltd, Poole, Dorset, England. The one stage procedure used for cellulase digestion is described by JonES and HAYwARD (1973). In the procedure, $200 \mathrm{mg}$ of ground sample were weighed into $25 \mathrm{ml}$ screw-capped bottles. $20 \mathrm{ml}$ of buffered enzyme were added and placed in an incubator at $40^{\circ} \mathrm{C}$ for 48 hours, shaking twice daily. After incubation, the mixture was filtered through filter paper, previously dried and weighed. The residue was washed well with water and acetone then dried overnight at $100^{\circ} \mathrm{C}$ and weighed. The cellulase digestibility was calculated as the percentage digested of the orginal $200 \mathrm{mg}$ sample. Nitrogen contents of the plant material were determined by the conventional Kjeldahl procedure. Crude protein was calculated by using the coefficient 6.25 .

\section{Results}

\subsection{Cellulase and in vitro digestibility}

The samples collected from May 23 to July 22 showed cellulase digestibility values of $74.2-44.4 \%$ for the clover-grass mixture and $76.1-40.3 \%$ for the pure couch grass stand (Table 1). The respective in vitro values were $82.1-61.4 \%$ and $84.9-58.0 \%$. At early stages of maturity when digestibility was high the cellulase technique gave relatively higher values than at later stages when digestibility was low. In consequence, when cellulase and in vitro values are compared, the difference between the two techniques was 9.1-9.5 units at early stages of maturity and $17.3-18.5$ units at advanced maturity (Table 1).

Correlations between cellulase and in vitro digestibility were high in both types of stand, as shown by the values $r=.99^{* * *}$ for the clover-grass mixture

Table 1. Raw values of cellulase digestibility and in vitro digestibility (\%) of a clover-grass mixture and couch grass at different stages of maturity.

\begin{tabular}{|c|c|c|c|c|c|c|}
\hline & \multirow{2}{*}{$\begin{array}{l}\text { Digestibility } \\
\text { class }\end{array}$} & \multicolumn{2}{|c|}{ Cellulase } & \multicolumn{2}{|c|}{ In vitro } & \multirow{2}{*}{$\begin{array}{l}\text { Difference } \\
\% \text {-units }\end{array}$} \\
\hline & & range & $\overline{\text { mean }}$ & range & $\overline{\text { mean }}$ & \\
\hline \multirow[t]{3}{*}{ Clover-grass } & high & $74.2-66.5$ & 70.4 & $82.1-77.4$ & 79.9 & 9.5 \\
\hline & medium & $63.9-50.3$ & 57.1 & $76.6-66.2$ & 71.4 & 14.3 \\
\hline & low & $47.7-44.4$ & 46.1 & $65.4-61.4$ & 63.4 & 17.3 \\
\hline \multirow[t]{3}{*}{ Couch grass } & high & $76.1-69.4$ & 72.8 & $84.9-78.8$ & 81.9 & 9.1 \\
\hline & medium & $64.9-53.2$ & 59.1 & $76.9-67.5$ & 72.2 & 13.1 \\
\hline & low & $47.5-40.3$ & 43.9 & $66.7-58.0$ & 62.4 & 18.5 \\
\hline
\end{tabular}


Table 2. Correlation of cellulase digestibility with in vitro digestibility and protein contents of plant material.

\begin{tabular}{ccccccc}
\hline Material & $\begin{array}{c}\text { Mean value } \\
\text { for } x\end{array}$ & $\begin{array}{c}\text { Range of } \\
\mathrm{x}\end{array}$ & $\mathrm{r}$ & Coefficient & $\begin{array}{c}\text { Residual } \\
\text { standard } \\
\text { deviation }\end{array}$ & $\begin{array}{c}\text { Regression } \\
\text { equatio }\end{array}$ \\
\hline
\end{tabular}

Correlation of cellulase digestibility $(x)$ with in vitro digestibility (y)

$\begin{array}{lllllll}\text { Clover-grass } & 59.1 & 74.2-44.4 & .99 * * * & 98.6 & 0.9 & \mathrm{y}=0.64 \mathrm{x}+34.07 \\ \text { Couch grass } & 59.5 & 76.1-40.3 & .99 * * * & 98.0 & 1.3 & \mathrm{y}=0.71 \mathrm{x}+30.69\end{array}$

Correlation of cellulase digestibility $(\mathrm{x})$ with protein content $(\mathrm{y})$

\begin{tabular}{lllllll} 
Clover-grass & 60.5 & $74.2-44.4$ & $.99 * * *$ & 98.9 & 0.6 & $y=0.50 x-9.52$ \\
Couch grass & 61.0 & $76.1-40.3$ & $.99 * * *$ & 99.6 & 0.5 & $y=0.57 x-12.65$ \\
\hline
\end{tabular}

and $\mathrm{r}=.99 * * *$ for couch grass (Table 2). The residual standard deviations (RSD) were 0.9 and 1.3 resepctively.

Regression lines (Fig. 1) show a slight difference in slopes for the two types of material studied. At a high level of in vitro digestibility; the cellulase digestibility values for couch grass are lower than those for the clover-grass mixture. This result may be due to the higher protein content of couch grass, as pointed out later. In Fig. 1, the dotted line represents the regression obtained by JONES and HAYWARD (1973) between cellulase and in vivo digestibility. Their regression line agrees very well with the results obtained at Viikki.

\subsection{Cellulase digestibility and protein content}

The cellulase digestibility follows closely plant protein content as the crop stand advances in maturity. Table 2 shows a good correlation between the cellulase digestibility and the protein content of the material studied. The values obtained were $r=.99^{* * *}$ for the clover-grass mixture and $r=.99 * * *$ for couch grass. The RSD values were 0.6 and 0.5 respectively. As mentioned earlier, at the same level of protein content the digestibility of couch grass was lower than the digestibility of the clover-grass mixture. (Fig. 2).

\subsection{Development of the digestibility during the growing season}

The use of the cellulase digestion technique and the in vitro method were studied at eighteen different times during the growing season. The results (Fig. 3) show a cubic effect of maturity upon digestibility for both of the materials studied. The two types of stand showed very similar trends. The regression equations between time $(x)$ and DM digestibility $(y)$ were as follows:

\footnotetext{
Grass-clover: Cellulase $\mathrm{y}=73.7+0.0801 \mathrm{x}-0.0901 \mathrm{x}^{2}+0.0031 \mathrm{x}^{3}$

In vitro $y=91.9-0.0354 x-0.0128 x^{2}+0.00014 x^{3}$

Couch grass: Cellulase $y=75.1+0.1601 x-0.0031 x^{2}+0.00038 x^{3}$

In vitro $y=84.1+0.0445 x-0.0172 x^{2}+0.00016 x^{3}$
}

Cellulase and in vintro values for the clover-grass mixture and cohuch grass (Fig. 3) were identica at the beginning of Jyly and represented cellulase 
and in vitro DM values of $50 \%$ and $67.5 \%$ respectively. This digestibility level represents roughly a $15 \%$ protein content of the plant material as indicated in Fig. 2.

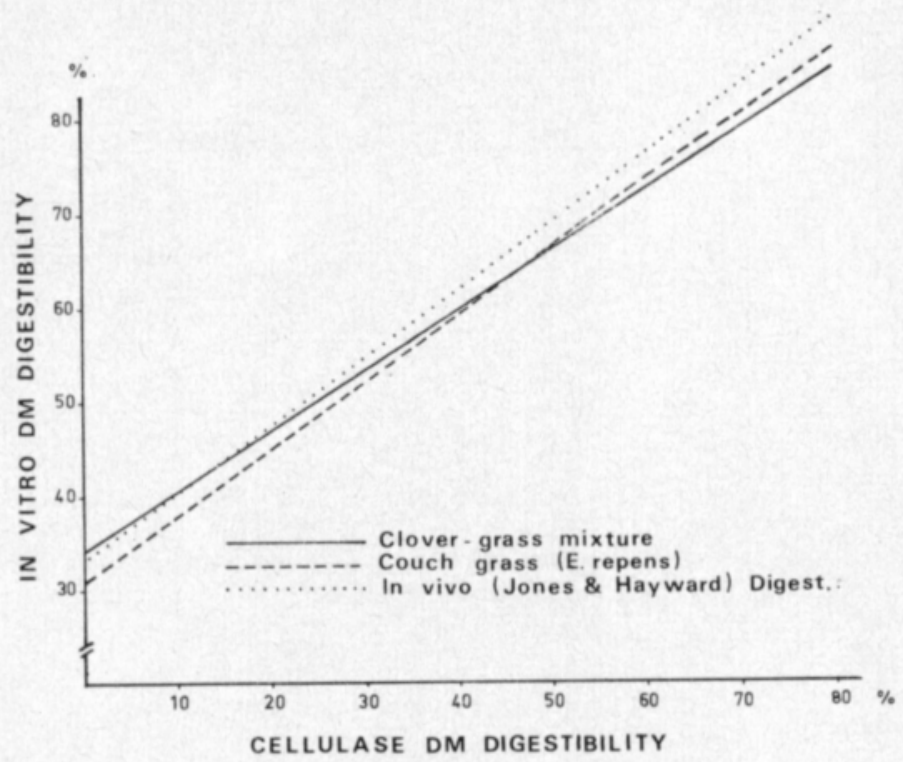

Fig 1. Regression between cellulase and in vitro DM digestibility for clover-grass mixture and couch grass compared with regression between cellulase and in vivo DM digestibility obtained by Jones and Hayward for various grasses.

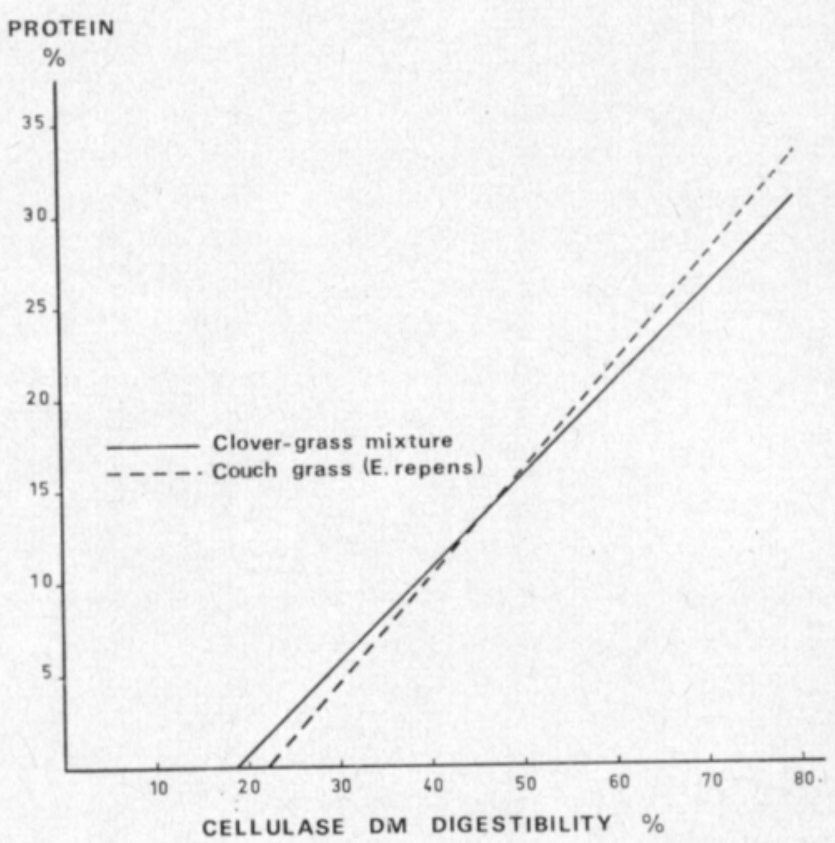

Fig 2. Regression between cellulase DM digestibility and plant DM protein content for clover-grass mixture and for couch grass. 


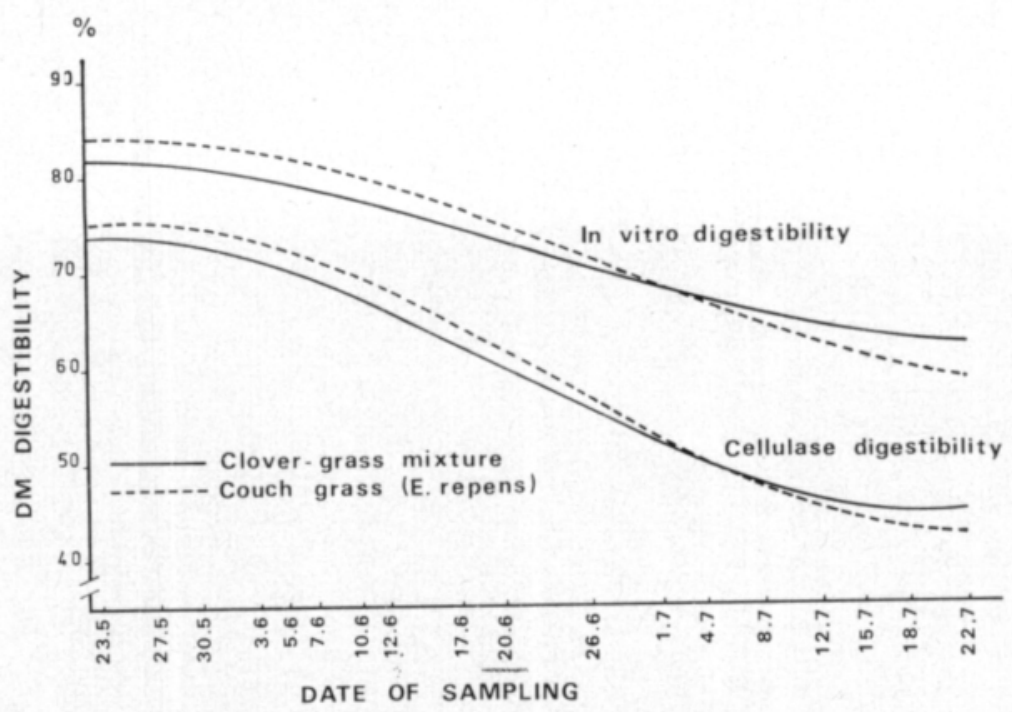

Fig. 3. Cellulase and in vitro digestibility of clover-grass mixture and couch grass at different stages of maturity during the growing season.

\section{Discussion}

In the study, the commercially available cellulase preparation was found to be useful. In the digestion the buffer-enzyme mixture worked uniformly throughout the series of tests. The use of a 48 hour digestion period proved to be satisfactory. Shorter periods of digestion have also been used successfully (ABE at al 1973). The filtration of the digested material was made with filter paper instead of crucibles as recommended by Jones and HAYwARD (1973). The use of filter paper needs special care in drying and weighing the paper. The use of acetone as an agent did not cause any difficulties although some loss of filter paper $(\mathbf{1 . 5}-\mathbf{2 . 0} \mathrm{mg} /$ paper $)$ was found.

The enzyme digestion technique produced results highly correlated with those of the in vitro digestion technique, which is widely used in Finland. As mentioned earlier, several studies revealed good correlations between cellulase digestibility and in vivo digestibility and prove the method reliable. As in vivo and in vitro digestibility values are practically identical, the present results support earlier findings. It is suggested that studies on the feasibility of using enzyme preparations for estimating the digestibility of legumes would be wortwhile.

As the cellulase technique has many advantages over the in vitro method, the use of the new method is recommended for agronomists and plant breeders, especially when rumen liquor is not available.

Acknowledgements. The author is grateful to Professor Esko Poutiainen and Dr. Maija-Liisa Salo, Dept. of animal Husbandry, for their interest in this work and for providing laboratory facilities for the tests. 


\section{REFERENCES}

AвE, A., Horii, S. \& Kaмzoka, K. 1972. Development and application of cellulase hydrolysis for predicting digestibility of roughage I. Digestion of cell-well carbohydrates by cellulase. Jap. J. Zootechn. Sei. 43:141-145. Ref. Nutr. Abstr: Rev. 43:4047-49.

Armstrong, D. G., Alexander, R. H. \& Mc Gowan, M. 1964. The use of in vitro digestibilities of dried grasses for the prediction of their energy values for ruminants. Proc. Nutr. Soc. 22: XXVI-XXVIII.

BAILEy, R. W. \& Jones, D. I. H. 1971. Pasture quality and ruminant nutrition. 3. Hydrolysis of rye-grass structural carbohydrates with carbohydrases in relation to rumen digestion. N. Z. J. Agric. Res. 14:847-857.

Donofer, E., Niemann, P. J., Crampton, E. W. \& Lloyd, G. E. J. 1963. Dry matter disappearance by enzyme and aqueous solution to predict the nutritive value of foreages. J. Dairy Sci. 46: $965-970$.

Drew, K. R. 1966. The in vitro prediction of herbage digestibility. Proc. N. Z. Soc. Anim. Prod. 26: 52-70.

Griffith, G. ap. \& Thomas, D. C. 1955. The use of normal acid fibre and A.O.A.C. fibre determinations for the estimation of herbage digestibility. Agric. Progr. 30: 124-128.

Guggozl, J. Saunders, R. M., Kohler, G. O. \& Kloppenstein, T. J. 1971. Enzymatic evaluation of processes for improving agricultural wastes for ruminant feeds. J. Anim. Sci. 33: $167-170$.

Jarrige, P., Thivand, P. \& Demarguilly, C. 1970. Development of a cellulolytic enzyme digestion for predicting the nutritive value of forages. Proc. XI Int. Grassl. Congr. Queensland, Australia. pp. 762-766.

Jones, D. I. H. \& BAILEY, R. W. 1972. The hydrolysis of cell-wall polysaccharides from freezedried and oven-dried herbage by rumen and mould carbohydrases. J. Sci. Food Agric. 23: $609-614$.

Jones, D. I. H. \& M. V. HAYWARD. 1973. A cellulase digestion technique for predicting the dry matter digestibility of grasses. J. Sci. Fd. Agric. 24: 1419-1426.

KivimÁe, A. 1960. Estimation of the digestibility of grassland crops from their chemical composition. Proc. 8. Intern. Grassl. Congr. 466-470.

Mc Megkan, C. P. 1943. A note on the relationship between crude fibre and the digestibility of organic matter. N. Z. J. Sci. Technol. Sect. A 25:152-156.

Salo, Maija-Lirsa 1973. Analytisk bestämning av vallväxternas fordervärde. N. J. F:s symposium: Foraedling for kvalitet hos foderplanter. Okt. 1973.

SoEst, P. J. van. 1963. Use of detergents in the analysis of fibrous feeds. I Preparation fo fiber residues of low nitrogen content. II. A rapid method for the determination of fiber and lignin. A.O.A.C. 46: 825-835.

Tilley, J. M. A. \& Terry, R. A. 1963. A two-stage technique for the in vitro digestion of forage crops. J. Br. Grassl. Soc. 18: 104-111.

Troelsen, J. E. \& HANel, D. J. 1966. Ruminant digestion in vitro as affected by inoculum donor, collection day and fermentation tim. Can. J. Anim. Sci. 46: 149-156.

YAtes, N. G. \& Allden, W. G. 1966. A study of herbage digestibility using an in vitro fermentation technique. Proc. Aust. Soc. Anim. Prod. VI: $340-349$.

MS received January 6, 1976 


\title{
SELOSTUS
}

\section{Sellulaasi- ja in vitro-sulavuuden vertailua eri kasvuasteen nurmirehuilla}

\author{
Seppo Pulli \\ Helsingin Yliopisto, Kasvinviljelytieteen laitos, Viikki
}

Tutkimuksessa verrattiin kemiallista sellulaasi-sulavuutta biologis-kemialliseen in vitrosulavuuteen apila-heinä sekanurmella ja juolavehnällä. Kasvustot edustivat vuoden 1974 kasvukautta ja näytteet 18 eri kehitysvaihetta kasvukauden alusta heinäkuun loppuun. Yksivaiheinen sellulaasisulatus tehtiin JoNEs \& HAYwARD (1973) menetelmällä ja kaksivaiheinen in vitro sulatus TILLEY \& TERRY (1963) metodiikalla. Raakaproteiinipitoisuus määritettiin Kjeldahl-menetelmällä.

Sellulaasi- ja in vitro sulavuuden välillä vallitsi kummallakin kasvustotyypillä kiinteä lineaarinen suhde, kuten korrelaatiokerroin $r=.99 * * *$ osoittaa. Sellulaasi-entsyymi osoitti suhteellisesti enemmän aktiivisuutta kasvin aikaisessa kehitysvaiheessa kuin myöhemmässä kehitysvaiheessa, joten ero sellulaasi- ja in vitro sulavuuden välillä suureni kasvin vanhetessa. Sellulaasisulavuuden ja in vitro-sulavuuden välisen regressiosuoran suunta oli lähes yhteneväinen JoNEs \& HAYWARD (1973) saaman sellulaasi- ja in vivo sulavuuden välisen suoran kanssa.

Sellulaasisulavuuden ja proteiinipitoisuuden välillä vallitsi kiinteä korrelaatio $(\mathrm{r}=.99 * * *)$ molemmilla kasvustotyypeillä, mikä merkitsee sitä, että proteiinipitoisuutta voidaan pitää tietyssä määrin myös kasvuston sellulaasi sulavuuden mittana. Lisätutkimuksia kuitenkin tarvitaan mm, eri ravinnetasojen ja erilaisten streessitekijöiden, kuten kuivuuden vaikutuksen selvittämiseksi.

Kun tutkituilla kasvustotyypeillä proteiinipitoisuus ja in vitro sulavuus olivat korkeita, sellulaasi tehosi heinä-apila seokseen paremmin kuin juolavehnäån. Tämä saattaa johtua tiettyjen vaikeasti sulavien yhdisteiden kuten ksylaanien runsaasta olemassaolosta heinillä. Sulavuuden muutokset kasvin kehitysvaiheen myötä edustivat kolmannen asteen regressiosuoraa molemmilla kasvustotyypeillä.

Tutkimuksessa testattu sellulaasi-metodi osoittautui nopeaksi, luotettavaksi ja helppokäyttöiseksi. Menetelmän etuna in vitro-menetelmään verrattuna on se, että fistelieläimiä ei tarvita ja menetelmä soveltuu käytettäväksi vaatimattomissakin laboratorio-olosuhteissa.

Useat ulkomaiset tutkimukset osoittavat läheisen yhteyden sellulaasisulavuuden ja in vivo-sulavuuden välillä. Koska in vivo- ja in vitro-sulavuudet ovat lähes yhtenåiset, tămän tutkimuksen tulokset tukevat aikaisempia havaintoja.

Suoritettujen tutkimusten pohjalta voidaan sellulaasimenetelmää suositella kasvinviljelytutkimuksiin. Erikoisen käyttökelpoinen se on koeasemaolosuhteissa. Menetelmää voidaan suositella myōs nurmikasvien jalostajille, koska sillä saadaan nopeasti ja pienistä näytteistä suhteellisen luotettavaa tietoa. 